\title{
Penerapan Model Pembelajaran Problem Based Learning untuk Meningkatkan Hasil Belajar Matematika Siswa
}

\section{Pt Hesti Mardika Astuti ${ }^{*}$, Gd Wira Bayu², Ni Nym Arca Aspini3 ${ }^{3}$}

1,2 Universitas Pendidikan Ganesha, Singaraja, Indonesia

${ }^{3}$ SD Negeri 2 Banyuning, Singaraja, Indonesia

\section{ART I CLE IN F O}

Article history:

Received April 12, 2021

Revised April 14, 2021

Accepted June 26, 2021

Available online August 25, 2021

Kata Kunci:

Problem Based Learning, Hasil

Belajar Matematika

Keywords:

Problem Based Learning, Math Learning Outcomes

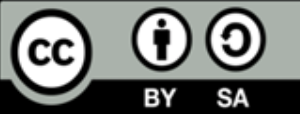

This is an open access article under the CC BY-SA license.

Copyright @ Universitas Pendidikan Ganesha. All rights reserved.

\begin{abstract}
A B S T R A K
Rendahnya hasil belajar Matematika siswa disebabkan oleh media pembelajaran yang kurang inovatif dan kurangnya keterkaitan antara materi pembelajaran dan konteks kehidupan nyata. Berdasarkan hal tersebut, maka diadakan penelitian yang bertujuan untuk meningkatkan hasil belajar matematika siswa kelas IV setelah penerapan model pembelajaran Problem Based Learning. Penelitian ini merupakan penelitian tindakan kelas yang dilaksanakan dalam dua siklus. Setiap siklus terdiri atas 4 tahapan yaitu: perencanaan, pelaksnaan, observasi, dan refleksi. Subjek penelitian ini adalah siswa kelas IV yang berjumlah 31 orang terdiri atas 16 laki-laki dan 15 perempuan. Objek penelitian adalah hasil belajar matematika siswa. Data dianalisis menggunakan statistik deskripsitif. Hasil penelitian menunjukkan bahwa model pembelajaran Problem Based Learning dapat meningkatkan hasil belajar matematika siswa kelas IV. Hal ini diketahui dari hasil belajar siswa prasiklus dengan nilai rata-rata sebesar 60,32 dan ketuntasan belajar $45,16 \%$ berada pada kategori rendah. Pada siklus I hasilnya mengalami dengan nilai rata-rata sebesar 65,81 dan ketuntasan belajar $54,84 \%$ yang berada pada kategori cukup. Penelitian dilanjutkan pada siklus II dan memperoleh nilai rata-rata sebesar 76,29 serta ketuntasan belajar $83,87 \%$ yang berada pada kategori tinggi dan sudah memenuhi kriteria indikator keberhasilan penelitian. Jadi, dapat disimpulkan bahwa penerapan model pembelajaran Problem Based Learning dapat meningkatkan hasil belajar Matematika siswa.
\end{abstract}

\section{A B S T R A C T}

The low mathematics learning outcomes of students are caused by less innovative learning media and the lack of linkage between learning materials and real-life contexts. Based on this, a research was conducted that aims to improve the mathematics learning outcomes of fourth grade students after the application of the Problem Based Learning model. This research is a classroom action research conducted in two cycles, each cycle consisting of 4 stages, namely: planning, implementation, observation, and reflection. The subjects in this study were fourth grade students, totaling 31 people consisting of 16 boys and 15 girls. The object of research is the result of students' mathematics learning. Data were analyzed using descriptive statistics. The results showed that the Problem Based Learning learning model can improve the mathematics learning outcomes of fourth grade students. This is evidenced by the pre-cycle student learning outcomes with an average score of 60.32 and learning completeness of $45.16 \%$ in the low category, experiencing an increase in the first cycle with an average score of 65.81 and learning completeness $54.84 \%$. which is in the sufficient category. The research was continued in cycle II and obtained an average score of 76.29 and learning completeness of $83.87 \%$ which was in the high category and had met the criteria for research success indicators. So, it can be concluded that the application of the Problem Based Learning learning model can improve students' mathematics learning outcomes.

\section{PENDAHULUAN}

Matematika adalah salah satu cabang ilmu pengetahuan yang mempunyai peranan penting dalam perkembangan ilmu pengetahuan dan teknologi, baik sebagai alat bantu dalam penerapan bidang ilmu lain maupun dalam pengembangan matematika itu sendiri yang dalam proses pembelajarannya sangat banyak terdapat rumus, angka, dan simbol-simbol matematis (Muhammad, 2016; Simanungkalit, 2016). 
Matematika diberikan sejak usia sekolah dasar dengan tujuan untuk melatih daya pikir seseorang, yang membuatnya kreatif dalam memecahkan masalah-masalah, sehingga dapat meningkatkan minat belajar siswa (Astuti, 2021; Fadillah, 2016). Pembelajaran Matematika untuk anak sekolah dasar tentu menjadi strategi khusus dalam melaksanakan pembelajaran yang didukung oleh kemampuan guru dalam merencanakan dan melaksanakan pembelajaran, sehingga tercipta pembelajaran yang bersifat PAIKEM (Ari Pertiwi, 2018; Siregar et al., 2017). Iklim lingkungan belajar siswa SD masih berada pada tahap konkret, sehingga sangat diharapkan pembelajaran Matematika dapat menciptakan suasana yang mampu memberikan alasan yang logis tentang peristiwa sehari-hari dan juga dapat mengklasifikasikan objek sesuai dengan jenisnya masing-masing untuk meningkatkan kemampuan berpikir siswa (Puspaningtyas, 2019; Widiantari N K M et al., 2016). Pembelajaran matematika di SD sering ditakuti oleh siswa. Lemahnya penguasaan matematika di SD disebabkan oleh beberapa faktor, diantaranya kesulitan siswa dalam pemahaman konsep-konsep matematika, tidak tersedianya alat peraga matematika, dan tidak adanya media yang mendukung pembelajaran. Selain hal tersebut, penanaman konsep yang kurang tepat juga merupakan salah satu penyebab lemahnya penguasaan Matematika. Pemahaman konsep yang dimiliki seseorang dapat digunakan untuk memecahkan suatu permasalahan yang berkaitan dengan pengetahuan yang telah ia miliki (Darjiani et al., 2015; Kadek et al., 2017). Pembelajaran yang dilaksanakan pada tahap awal atau dasar harus benar-benar mantap karena kesulitan belajar yang dialami siswa di tahap awal akan berpengaruh terhadap belajar pada tahap selanjutnya (Widyasari et al., 2015).

Berdasarkan hasil studi dokumentasi dari daftar nilai penilaian akhir semester (PAS) Semester I yang dimiliki guru menunjukkan bahwa hasil belajar Matematika siswa kelas IV masih rendah dengan rata-rata 60,32. Dari 31 orang siswa hanya 14 orang dengan persentase 45,16\% siswa yang tuntas dengan nilai di atas KKM yang sudah ditetapkan, yaitu sebesar 62. Sedangkan 17 orang siswa dengan persentase $54,84 \%$ belum tuntas atau masih berada di bawah nilai KKM. Hasil observasi pembelajaran Matematika yang dilaksanakan pada 20 Januari 2021, diketahui bahwa proses pembelajaran Matematika dibelajarkan secara daring sesuai dengan situasi pandemi Covid-19 saat ini. Ketika pelaksanaan observasi pembelajaran, ditemukan beberapa permasalahan, diantaranya: pembelajaran masih bersifat konvensional (teacher centered), media yang digunakan kurang bervariasi, sehingga siswa cepat merasa bosan, kurangnya kreativitas dan rasa ingin tahu siswa dalam mengerjakan tugas dan guru kurang mengaitkan materi pelajaran dengan konteks kehidupan nyata. Permasalahan tersebut menyebabkan hasil belajar siswa rendah. Indikator keberhasilan yang dilaksanakan hanya pada aktivitas siswa tanpa melihat perolehan hasil belajar siswa. Hasil belajar mencakup tiga ranah yaitu: ranah kognitif, afektif, dan psikomotor (Qadar, 2015). Permasalahan yang berkaitan dengan rendahnya hasil belajar Matematika ditemukan pada penelitian yang dilakukan oleh (Fahri, 2014; Lutfita Sari \& Dewi Koeswanti, 2019). Selain itu, permasalahan yang serupa juga ditemukan oleh (Safrida \& Kistian, 2020; Wijayama, 2020). Apabila permasalahan tersebut dibiarkan, maka akan berdampak pada rendahnya hasil belajar Matematika siswa, kurangnya keaktifan siswa dalam belajar, serta pembelajaran kurang bermakna. Berdasarkan permasalahan tersebut, maka dipandang perlu untuk melakukan penelitian dengan menerapkan model pembelajaran yang inovatif.

Solusi yang diberikan untuk memecahkan permasalahan guna meningkatkan hasil belajar Matematika siswa yakni dengan menerapkan model pembelajaran Problem Based Learning yang sesuai dengan situasi dan kondisi yang ada. Model pembelajaran Problem Based Learning dapat menempatkan siswa sebagai pusat pembelajaran yang menuntut adanya aktivitas siswa secara penuh dalam rangka menyelesaikan setiap permasalahan yang dihadapi siswa secara mandiri dengan cara mengonstruksi pengetahuan dan pemahaman yang dimiliki (Saputro et al., 2019; Yandhari et al., 2019). Penerapan model pembelajaran Problem Based Learning dapat memotivasi siswa untuk belajar, siswa dapat terlibat secara aktif dalam pembelajaran, dapat melakukan kolaborasi kerja dalam memecahkan permasalahan, serta memiliki berbagai keterampilan, pengalaman, dan berbagai konsep untuk dapat dipecahkan secara bersama-sama (Asriningtyas et al., 2018; Fauzia, 2018). Dengan adanya penerapan model pembelajaran Problem Based Learning, siswa dapat meningkatkan motivasi dan aktivitas dalam pembelajaran, mampu mentransfer pengetahuan untuk memahami permasalahan yang dihadapi, dapat melakukan evaluasi sendiri baik terhadap hasil maupun proses belajar yang telah dilakukan, mampu mengembangkan kemampuan siswa untuk berpikir kritis serta dapat memberikan kesempatan bagi siswa untuk mengaplikasikan pengetahuan yang mereka miliki dalam dunia nyata (Lestari \& Projosantoso, 2016). Model Problem Based Leaning dapat meningkatkan antusiasme siswa dalam proses pembelajaran, sehingga siswa mempunyai perspektif yang luas tentang pemecahan masalah, termasuk di dalamnya proses kreatif dalam pembelajaran (Pertiwi, 2018). Model pembelajaran Problem Based Learning dapat membangkitkan minat siswa, nyata, dan sesuai untuk membangun kemampuan intelektual (Fitri, 2017). Model pembelajaran Problem Based Learning mengutamakan permasalahan nyata, baik di lingkungan 
sekolah, rumah, maupun masyarakat sebagai dasar untuk memperoleh pengetahuan dan konsep melalui kemampuan berpikir kritis dan memecahkan masalah (Asriningtyas et al., 2018). Alasan penggunaan model Problem Based Learning pada penelitian ini yaitu meningkatkan aktivitas belajar siswa dan prestasi akademiknya, membantu siswa dalam memecahkan permasalahan pembelajaran melalui pengalaman langsung, meningkatkan kemampuan dalam menerapkan konsep-konsep pada permasalahan baru/nyata. Selain itu, peningkatan hasil belajar sangat diharapkan setelah diterapkannya model Problem Based Learning. Berdasarkan uraian tersebut, maka penelitian ini bertujuan untuk meningkatkan hasil belajar Matematika setelah diterapkannya model pembelajaran Problem Based Learning.

\section{METODE}

Penelitian ini termasuk penelitian tindakan kelas (PTK). Penelitian tindakan kelas dapat didefinisikan sebagai suatu penelitian tindakan (action research) yang dilakukan oleh guru yang sekaligus sebagai peneliti di kelasnya atau bersama-sama dengan orang lain (kolaborasi) dengan jalan merancang, melaksanakan, dan merefleksikan tindakan secara kolaboratif dan partisipatif yang bertujuan untuk memperbaiki atau meningkatkan mutu proses pembelajaran di kelasnya melalui suatu tindakan tertentu dalam suatu siklus (Pahlawan \& Tambusaii, 2019). Penelitian tindakan kelas dilakukan dengan tujuan untuk dapat menemukan konsep sendiri pembelajaran dan meningkatkan hasil belajar siswa (Afandi, 2014; Surya, 2018). Secara umum tahapan penelitian tindakan kelas meliputi kegiatan: perencanaan, pelaksanaan, observasi, dan refleksi. Adapun rancangan penelitiannya seperti pada gambar 1.

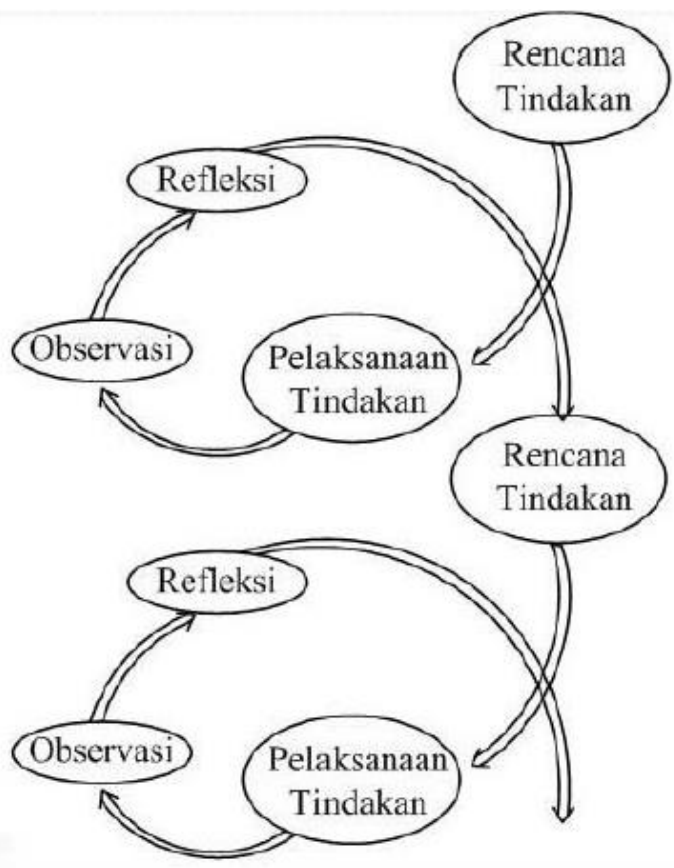

Gambar 1. Spiral Rancangan Penelitian Tindakan Kelas (Sumber :(Permana, 2015)

Subjek penelitian adalah tempat peneliti memperoleh keterangan atau data penelitian. Yang menjadi subjek penelitian ini adalah siswa kelas IV SD Negeri 1 Anturan yang berjumlah 31 orang, terdiri dari 16 orang siswa laki-laki dan 15 orang siswa perempuan. Data yang diupayakan untuk diperoleh dalam penelitian ini menyangkut tindakan yang yang akan dijadikan alternatif untuk memperbaiki kondisi yang ada. Oleh karean itu, ditentukan objek secara jelas agar yang diharapkan dapat tercapai dengan baik. Objek dalam peneltian ini adalah peningkatan hasil belajar Matematika siswa kelas IV SD Negeri 1 Anturan. Teknik pengumpulan data pada penelitian ini berupa tes. Teknik tes digunakan untuk memperoleh data tentang hasil belajar Matematika. Teknik tes dalam hal ini adalah pos-tes dilaksanakan sebanyak dua kali yaitu pos-tes siklus I dan pos-tes siklus II. Pos-tes siklus I diberikan setelah pertemuan ke tiga dari siklus I berakhir, sedangkan pos-tes siklus II diberikan setelah pertemuan ke tiga dari siklus II berakhir. Tujuan pemberian pos-tes pada akhir siklus yaitu untuk mengetahui hasil belajar Matematika siswa setelah diberikan tindakan atau perlakuan. Instrumen pengumpulan data yang digunakan pada penelitian ini berupa soal objektif yang berjumlah 20 butir soal. Soal dijawab oleh setiap siswa secara tertulis pada lembar jawaban yang sudah disediakan dengan tujuan untuk mengetahui hasil belajar siswa 
pada mata pelajaran Matematika. Untuk menentukan secara jelas ruang lingkup penelitian dan sebagai petunjuk dalam menulis butir instrumen, harus ditentukan kisi-kisi dari instrumen yang akan disusun. Kisi-kisi instrumen disusun berdasarkan objek pelaksanaan tindakan yang dilakukan di kelas. Adapun kisi-kisi instrumen yang digunakan seperti pada Tabel 1.

Tabel 1. Kisi-kisi Instrumen Penelitian

\begin{tabular}{|c|c|c|c|c|}
\hline No & Kompetensi Dasar & $\begin{array}{l}\text { Materi } \\
\text { Pokok }\end{array}$ & Indikator & $\begin{array}{c}\text { Nomor } \\
\text { Soal }\end{array}$ \\
\hline \multicolumn{5}{|c|}{ SIKLUS I } \\
\hline \multirow[t]{9}{*}{1} & 3.9 Menjelaskan dan menentukan & Bangun & Menghitung keliling persegi & 1,2 \\
\hline & $\begin{array}{l}\text { keliling dan luas persegi, persegi } \\
\text { panjang dan segitiga serta }\end{array}$ & Datar & $\begin{array}{l}\text { Menghitung keliling persegi } \\
\text { panjang }\end{array}$ & 3,4 \\
\hline & hubungan pangkat dua dengan & & Menghitung keliling segitiga & 5,6 \\
\hline & akar pangkat dua. & & $\begin{array}{l}\text { Menyelesaikan masalah yang } \\
\text { berkaitan dengan keliling } \\
\text { bangun datar }\end{array}$ & $7,8,9$ \\
\hline & & & Menghitung luas persegi & 10,11 \\
\hline & & & $\begin{array}{l}\text { Menghitung luas persegi } \\
\text { panjang }\end{array}$ & 12,13 \\
\hline & & & Menghitung luas segitiga & 14,15 \\
\hline & & & Menyelesaikan masalah yang & 16,17 \\
\hline & & & $\begin{array}{l}\text { terkait dengan luas bangun } \\
\text { datar }\end{array}$ & $\begin{array}{l}18,19, \\
20\end{array}$ \\
\hline \multicolumn{5}{|c|}{ SIKLUS II } \\
\hline \multirow[t]{9}{*}{2} & $\begin{array}{l}\text { 3.10 Menjelaskan hubungan antar } \\
\text { garis (sejajar, berpotongan, } \\
\text { berhimpit) menggunakan } \\
\text { model konkret }\end{array}$ & $\begin{array}{l}\text { Hubungan } \\
\text { Antar Garis }\end{array}$ & $\begin{array}{l}\text { Menjelaskan hubungan antar } \\
\text { garis (sejajar, berpotongan, } \\
\text { berhimpit) }\end{array}$ & $1,2,3$ \\
\hline & $\begin{array}{l}\text { 3.11 Menjelaskan data diri peserta } \\
\text { didik dan lingkungannya }\end{array}$ & Statistika & $\begin{array}{l}\text { Mengumpulkan data dalam } \\
\text { kehidupan sehari-hari }\end{array}$ & 4 \\
\hline & $\begin{array}{l}\text { yang disajikan dalam bentuk } \\
\text { diagram batang }\end{array}$ & & $\begin{array}{l}\text { Menafsirkan data dalam } \\
\text { bentuk tabel }\end{array}$ & $\begin{array}{l}5,6,7, \\
8,9,10\end{array}$ \\
\hline & $\begin{array}{l}\text { 3.12 Menjelaskan dan menentukan } \\
\text { ukuran sudut pada bangun } \\
\text { datar dalam satuan baku }\end{array}$ & Sudut & $\begin{array}{l}\text { Menjelaskan pengertian sudut } \\
\text { dalam satuan baku dengan } \\
\text { benar }\end{array}$ & 11 \\
\hline & dengan menggunakan busur & & Menganalisis nama-nama & 12, 13, \\
\hline & derajat & & $\begin{array}{l}\text { sudut berdasarkan ukuran } \\
\text { besar sudut dengan tepat. }\end{array}$ & 14 \\
\hline & & & $\begin{array}{l}\text { Mengukur besar sudut benda } \\
\text { dalam kehidupan sehari-hari } \\
\text { dalam satuan baku } \\
\text { menggunakan busur derajat }\end{array}$ & 15 \\
\hline & & & $\begin{array}{l}\text { Menentukan besar sudut } \\
\text { dalam satuan baku } \\
\text { menggunakan busur derajat }\end{array}$ & 16,17 \\
\hline & & & $\begin{array}{l}\text { Menentukan besar sudut } \\
\text { suatu bangun datar } \\
\text { menggunakan busur derajat }\end{array}$ & $\begin{array}{l}18,19, \\
20\end{array}$ \\
\hline
\end{tabular}

Teknik analisis data yang digunakan untuk mengukur hasil belajar siswa pada penelitian ini menggunakan analisis data deskriptif kuantitatif yaitu dengan mencari rata-rata nilai siswa dan ketuntasan belajar siswa (Agung, 2010). Hasil analisis tingkat hasil belajar siswa yang diperoleh berdasarkan rata- rata nilai siswa dan ketuntasan belajarnya, selanjutnya dikonversi ke dalam Penilaian Acuan Patokan (PAP) skala lima. Keberhasilan suatu penelitian dapat dilihat dari kemajuan hasil belajar yang dicapai oleh siswa sesuai dengan KKM yang ditetapkan oleh sekolah yaitu memperoleh nilai secara individu minimal 62. Adapun indikator keberhasilan yang diinginkan oleh peneliti dalam penelitian ini 
yaitu: Rata-rata hasil belajar siswa secara klasikal mencapai 70\% dengan kategori tinggi dan ketuntasan belajar klasikal yang dicapai sebesar $80 \%$ dengan kategori tinggi.

\section{HASIL DAN PEMBAHASAN}

\section{Hasil}

Penelitian tindakan kelas ini dilaksanakan di SD Negeri 1 Anturan. Subjek penelitian adalah siswa kelas IV SD Negeri 1 Anturan dengan jumlah siswa sebanyak 31 orang, yang terdiri dari 16 orang siswa laki-laki dan 15 orang siswa perempuan. Pada penelitian tindakan kelas ini pembelajaran dilaksanakan secara daring berdasarkan situasi pandemi Covid-19 melalui Google Meet dan WhatsAap. Adapun rekapitulasi hasil belajar siswa dari kegiatan pra siklus, siklus I, sampai siklus II dapat dilihat pada Tabel 2 .

Tabel 2. Rekapitulasi Hasil Belajar Siswa dari Kegiatan Pra siklus, Siklus I, sampai Siklus II

\begin{tabular}{llccc}
\hline No & \multicolumn{1}{c}{ Aspek } & Pra Siklus & Siklus I & Siklus II \\
\hline 1 & Jumlah seluruh siswa & 31 & 31 & 31 \\
2 & Jumlah Nilai & 1870 & 2040 & 2365 \\
3 & KKM & 62 & 62 & 62 \\
4 & Nilai Rata-rata & 60,32 & 65,81 & 76,29 \\
5 & Nilai Tertinggi & 80 & 85 & 95 \\
6 & Nilai Terendah & 45 & 50 & 60 \\
7 & Jumlah Siswa Tuntas & 14 & 17 & 26 \\
8 & Jumlah Siswa Tidak Tuntas & 17 & 14 & 5 \\
9 & Presentase Ketuntasan Belajar & $45,16 \%$ & $54,84 \%$ & $83,87 \%$ \\
\hline
\end{tabular}

Berdasarkan data pada Tabel 2 diketahui bahwa pada kegiatan prasiklus nilai rata-rata dari 31 orang siswa adalah sebesar 60,32. Dari data tersebut hanya 14 orang dengan persentase 45,16\% yang mencapai kriteria keberhasilan sesuai indikator yang telah ditetapkan. Setelah hasil belajar siswa dibandingkan ke dalam PAP skala lima, maka tingkat hasil belajar siswa masih berada pada kategori rendah. Berdasarkan hal tersebut alternatif pemecahan masalah yang dilakukan adalah melaksanakan perbaikan pembelajaran dengan menerapkan model pembelajaran Problem Based Learning yang dilaksanakan pada kegiatan siklus I. Pada kegiatan siklus I yaitu mengukur hasil belajar siswa setelah dilaksanakannya pemberian post- tes siklus I berupa 20 butir soal objektif. Setelah dilakukan analisis diketahui bahwa nilai rata-rata dari 31 orang siswa adalah 65,81. Sedangkan persentase ketuntasan belajar yang dicapai oleh 17 orang siswa yaitu 54,84\%. Setelah hasil belajar siswa dibandingkan ke dalam PAP skala lima, maka tingkat hasil belajar siswa pada siklus I masih berada pada kategori cukup. Hal ini menunjukkan terjadinya peningkatan hasil belajar siswa dari kegiatan sebelumnya. Namun, merujuk dari hasil tersebut penelitian ini belum mencapai indikator keberhasilan yang telah ditetapkan, sehingga harus dilanjutkan pada pelaksanaan siklus II untuk mendapatkan peningkatan hasil belajar siswa sesuai dengan indikator keberhasilan yang telah ditetapkan. Pada kegiatan siklus II adalah mengukur hasil belajar siswa setelah dilaksanakannya pemberian post- tes siklus II berupa 20 butir soal objektif. Hasil yang diperoleh yaitu nilai rata-rata dari 31 orang siswa adalah 76,29 dengan persentase ketuntasan belajar mencapai 83,87\%, dan setelah hasil belajar siswa dibandingkan ke dalam PAP skala lima, maka tingkat hasil belajar siswa pada siklus II berada pada kategori tinggi. Hal ini menunjukkan kegiatan yang dilaksanakan pada siklus II telah dapat mencapai indikator keberhasilan yang ditetapkan, sehingga penelitian dapat dikatakan berhasil. Peningkatan hasil belajar siswa dari kegiatan prasiklus, siklus I, sampai siklus II dapat dilihat pada Tabel 3.

Tabel 3 . Peningkatan Hasil Belajar Matematika Siswa Kelas IV

\begin{tabular}{clccccc}
\hline No & \multicolumn{1}{c}{ Deskripsi } & Pra siklus & Peningkatan & Siklus I & Peningkatan & Siklus II \\
\hline 1 & Rata-rata nilai siswa & 60,32 & 5,49 & 65,81 & 10,48 & 76,29 \\
2 & Ketuntasan belajar siswa & $45,16 \%$ & $9,68 \%$ & $54,84 \%$ & $29,03 \%$ & $83,87 \%$ \\
3 & Kategori PAP & Rendah & & Cukup & & Tinggi \\
\hline
\end{tabular}

Berdasarkan Tabel 3 diketahui bahwa bahwa rata-rata nilai siswa pada kegiatan pra siklus mencapai 60,32 dengan ketuntasan belajar siswa sebesar 45,16\% dan jika dikategorikan pada PAP skala lima berada pada kategori rendah, sehingga dilakukan tindakan pada siklus I. Pada siklus I rata-rata nilai siswa mencapai 65,81 dengan ketuntasan belajar sebesar 54,84\% dengan kategori cukup. Peningkatan hasil belajar pada kegiatan prasiklus menuju siklus I cukup meningkat, yaitu rata-rata nilai siswa 
meningkat sebesar 5,49 dan ketuntasan belajar meningkat sebesar 9,68\%. Selanjutnya, penelitian dilanjutkan pada siklus II dengan perolehan nilai rata-rata siswa sebesar 76,29 dengan ketuntasan belajar sebesar 83,87\% dan jika dikonversikan pada PAP skala lima berada pada kategori tinggi. Peningkatan hasil belajar siswa dari siklus I menuju siklus II sangat singnifikan. Hal ini diketahui dari peningkatan ratarata nilai siswa sebesar 10,48 dan ketuntasan belajar sebesar 29,03\%. Rata-rata nilai siswa dan ketuntasan hasil belajar siswa pada siklus II sudah mencapai ketentuan yang ditetapkan, yaitu rata-rata mencapai minimal > 70 dan ketuntasan belajar mencapai minimal 80\%, sehingga pada penelitian ini hanya dilaksanakan sampai pada siklus II karena indikator keberhasilan sudah dapat dicapai.

Hasil penelitian menunjukkan bahwa penerapan model pembelajaran Problem Based Learning dapat meningkatkan hasil belajar siswa karena penerapan langkah-langkah model pembelajaran Problem Based Learning yang terdiri dari beberapa tahap. Tahap satu, orientasi peserta didik pada masalah, pada tahap ini guru menginformasikan tujuan-tujuan pembelajaran, mendiskripsikan kebutuhan-kebutuhan logistik penting, dan memotivasi agar terlibat dalam kegiatan pemecahan masalah yang mereka pilih sendiri. Dengan adanya kegiatan orientasi pada masalah siswa dapat mengaitkan pengetahuan awal yang dimilikinya dengan pengetahuan baru yang akan dipelajarinya (Widyastuti \& Pujiastuti, 2014). Tahap dua, mengorganisasi peserta didik. Pada tahap ini guru membantu siswa menentukan dan mengatur tugastugas belajar yang berhubungan dengan masalah yang diberikan. Keaktifan siswa dalam proses pembelajaran membuat suasana kelas lebih hidup, hal ini dapat meningkatkan berkolaborasi siswa bersama temannya (Anwar \& Jurotun, 2019). Tahap tiga, membimbing penyelidikan individu maupun kelompok. Pada tahap ini guru mendorong siswa mengumpulkan informasi yang sesuai, melaksanakan eksperimen, serta mencari penjelasan dan solusi. Kegiatan ini sangat memberikan manfaat bagi siswa untuk meningkatkan kebermaknaan proses pembelajaran. Pembelajaran bermakna adalah pembelajaran yang mengaitkan aktivitas siswa dengan kehidupan sehari-hari/pengalaman (Gazali, 2016). Tahap empat, mengembangkan dan menyajikan hasil. Pada tahap ini guru membantu siswa merencanakan dan menyiapkan hasil karya siswa yang sesuai seperti laporan. Kegiatan ini melatih kemandirian, tanggung jawab, dan meningkatkan rasa kepercayaan diri siswa sehingga pembelajaran lebih berpusat pada siswa (Rafli, 2019). Tahap lima, menganalisis dan mengevaluasi proses dan hasil pemecahan masalah. Pada tahap ini guru membantu siswa melakukan refleksi atau penyelidikan dan proses-proses yang mereka gunakan. Kegiatan ini mampu membekali siswa konsep-konsep pembelajaran yang benar sesuai dengan karakteristik siswa (Shofiyah \& Wulandari, 2018; Yoesoef, 2015).

Penelitian ini didukung oleh penelitian yang menyatakan adanya peningkatan hasil belajar siswa melalui penerapan model Problem Based Learning (Puspita et al., 2018). Penelitian lain juga menyatakan bahwa dengan menerapkan model Problem Based Learning hasil belajar siswa meningkat (Khotimah, 2017). Penelitian yang serupa juga menyatakan bahwa adanya peningkatan pembelajaran dari siklus I menuju siklus II melalui penerapan model Problem Based Learning (Nurbaeti, 2019). Berdasarkan penelitian yang telah dilakukan tersebut, maka dapat dibuktikan bahwa setelah diterapkannya model Problem Based Learning, hasil belajar matematika siswa dapat ditingkatkan. Penerapan model pembelajaran Problem Based Learning memiliki beberapa implikasi yaitu siswa mampu mengaitkan permasalahan yang diberikan dengan kehidupan sehari-hari, pembelajaran yang dilakukan lebih bermakna dan berpusat pada siswa, siswa dapat meningkatkan daya ingat melalui kegiatan pemecahan masalah secara langsung, siswa dapat berkolaborasi bersama-sama untuk proses pemecahan masalah yang diberikan. Implikasi tersebut tentu masih memiliki beberapa kekurangan mengingat masih adanya keterbatasan pada penelitian ini. Keterbatasan yang ada pada penelitian ini yaitu keterbatasan penggunaan platform pembelajaran daring yang belum dapat dilaksanakan secara maksimal, sehingga sangat diharapkan adanya pengenalan dan pelatihan penggunaan platform pembelajaran yang lebih baik lagi. Observasi kegiatan pembelajaran hanya terbatas melalui sikap yang ditunjukkan oleh siswa tanpa adanya instrumen. Oleh sebab itu, sangat diharapkan adanya instrumen observasi untuk memperoleh hasil observasi yang valid. Objek penelitian ini masih terbatas pada hasil belajar siswa saja, sehingga perlu adanya penambahan objek penelitian seperti peningkatan keterampilan berpikir tingkat tinggi (HOTS), sehingga menjadi suatu penelitian yang utuh karena adanya keterkaitan antara keterampilan pemecahan masalah dan hasil belajar.

\section{SIMPULAN}

Penerapan model Problem Based Learning memberikan kesempatan kepada siswa untuk mengaitkan pengetahuan yang dimiliki dan pengetahuan baru yang akan dipelajari, meningkatkan keaktifan siswa dalam proses pembelajaran, memperoleh pembelajaran yang bermakna, meningkatkan kepercayaan diri siswa, serta mengembangkan konsep pembelajaran sesuai dengan karakteristik siswa. 


\section{DAFTAR PUSTAKA}

Afandi, M. (2014). Pentingnya Penelitian Tindakan Kelas bagi Guru dalam Pembelajaran di Sekolah Dasar. Jurnal Ilmiah Pendidikan Dasar UNISSULA, 1(1), 1-19. https://doi.org/10.30659/pendas.1.1.1-19.

Anwar, K., \& Jurotun, J. (2019). Peningkatan Aktivitas dan Hasil Belajar Siswa SMA pada Dimensi Tiga Melalui Model Pembelajaran PBL Berbantuan Alat Peraga. Kreano, Jurnal Matematika KreatifInovatif, 10(1), 94-104. https://doi.org/10.15294/kreano.v10i1.19366.

Ari Pertiwi, N. L. S. (2018). Penerapan Model Problem Based Learning Berbantuan Media Interaktif untuk Meningkatkan Hasil Belajar Matematika Siswa. Jurnal Ilmiah Pendidikan Profesi Guru, 1(1), 331339. https://doi.org/10.23887/jippg.v1i1.14262.

Asriningtyas, A. N., Kristin, F., \& Anugraheni, I. (2018). Penerapan Model Pembelajaran Problem Based Learning untuk Meningkatkan Kemampuan Berpikir Kritis dan Hasil Belajar Matematika Siswa Kelas 4 Sd. JIPMat, 3(1). https://doi.org/10.26877/jipmat.v3i1.2226.

Astuti, A. (2021). Pengembangan Lembar Kerja Peserta Didik (LKPD) Berbasis Problem Based Learning (PBL) untuk Kelas VII SMP/MTs Mata Pelajaran Matematika. Jurnal Cendekia : Jurnal Pendidikan Matematika, 5(2), 1011-1024. https://doi.org/10.31004/cendekia.v5i2.573.

Darjiani, N. N. Y., Meter, I. G., \& Negara, I. G. A. O. (2015). Analisis Kesulitan-Kesulitan Belajar Matematika Siswa Kelas V dalam Implementasi Kurikulum 2013 di SD Piloting Se-Kabupaten Gianyar Tahun Pelajaran 2014 / 2015. E-Journal PGSD Universitas Pendidikan Ganesha, 3(1), 1-11. https://ejournal.undiksha.ac.id/index.php/JJPGSD/article/view/5070.

Fadillah, A. (2016). Analisis Minat Belajar dan Bakat terhadap Hasil Belajar Matematika Siswa. M A T H L I $N$ E: Jurnal Matematika dan Pendidikan Matematika, 1(2), 113-122. https://doi.org/10.31943/mathline.v1i2.23.

Fahri, M. B. P. (2014). Penerapan Model Problem Based Learning (PBL) untuk Meningkatkan Hasil Belajar Siswa pada Materi Panjang Garis Singgung Persekutuan Dua Lingkaran di Kelas VIII SMP Negeri 19 Palu. Jurnal Elektronik Pendidikan Matematika Tadulako, 2(1), 67-77.

Fauzia, H. A. (2018). Penerapan Model Pembelajaran Problem Based Learning untuk Meningkatkan Hasil Belajar Matematika SD. Primary: Jurnal Pendidikan Guru Sekolah Dasar, 7(1), 40. https://doi.org/10.33578/jpfkip.v7i1.5338.

Fitri, F. (2017). Penerapan Model PBL pada Pelajaran Biologi untuk Meningkatkan Kompetensi dan Kemampuan Berpikir Kritis Siswa Kelas X SMA Negeri 19 Bandung Tahun Pelajaran 2014/2015. BIOSFER : Jurnal Biologi Dan Pendidikan Biologi, 1(1). https://doi.org/10.23969/biosfer.v1i1.198.

Gazali, R. Y. (2016). Pembelajaran Matematika yang Bermakna. Math Didactic, 2(3), 181-190. https://doi.org/10.33654/math.v2i3.47.

Kadek, N., Kusuma, D., Riastini, P. N., \& Pudjawan, K. (2017). Pengaruh Model Pembelajaran Arias terhadap Pemahaman Konsep Matematika pada Siswa Kelas V SD Negeri 1 Candikusuma. E-Journal PGSD $\begin{array}{llll}\text { Universitas Pendidikan } \quad \text { Ganesha, } & \text { 5ol. }\end{array}$ http://dx.doi.org/10.23887/jjpgsd.v5i2.11038.

Khotimah, K. (2017). Penerapan Model Problem Based Learning dengan Pendekatan. Eduscope, 03(02), 23-29.

Lestari, D. I., \& Projosantoso, A. K. (2016). Pengembangan Media Komik IPA model PBL untuk Meningkatkan Kemampuan Berpikir Analitis dan Sikap Ilmiah. Jurnal Inovasi Pendidikan IPA, 2(2), 145. https://doi.org/10.21831/jipi.v2i2.7280.

Lutfita Sari, T., \& Dewi Koeswanti, H. (2019). Penerapan Model Pembelajaran Berbasis Masalah untuk Meningkatkan Hasil Belajar. Journal of Education Action Research, 3(2), 153. https://doi.org/10.23887/jear.v3i2.17272.

Muhammad Daud Siagian. (2016). Kemampuan Koneksi Matematika dalam Pembelajaran Matematika. MES Journal of Mathematics Education and Science), 2, 58-67. https://doi.org/10.30743/mes.v2i1.117.

Nurbaeti, N. (2019). Penerapan Model Pembelajaran Problem Based Learning untuk Meningkatkan Hasil Belajar Matematika di Sekolah Menengah Pertama. Pedagogos ( Jurnal Pendidikan ), 1(2), 1-10. https://doi.org/10.33627/gg.v1i2.179.

Pahlawan, U., \& Tambusaii, T. (2019). Edukatif: Jurnal Ilmu Pendidikan Penerapan Metode Mind Mapping untuk Meningkatkan Kemampuan Berpikir Kreatif Siswa Sekolah Dasar Rizki Ananda 1. Jurnal Ilmu Pendidikan, 1(1), 1-8. https://doi.org/10.31004/edukatif.v1i1.1.

Permana, E. P. (2015). Penerapan Metode Problem Solving dengan Media Grafis pada Pembelajaran Tematik. Jurnal Pendidikan Dasar Nusantara, 1(1), 25-36. http://dx.doi.org/10.23960/jpp.

Puspaningtyas, N. D. (2019). Berpikir Lateral Siswa SD dalam Pembelajaran Matematika. Mathema Journal, 
1(1), 24-30.

Puspita, M., Slameto, S., \& Setyaningtyas, E. W. (2018). Peningkatkan Hasil Belajar Matematika Siswa Kelas 4 SD Melalui Model Pembelajaran Problem Based Learning. Justek: Jurnal Sains Dan Teknologi, 1(1), 120. https://doi.org/10.31764/justek.v1i1.416.

Qadar, R. (2015). Mengakses Aspek Afektif dan Kognitif pada Pembelajaran Optika dengan Pendekatan Demonstrasi Interaktif. Jurnal Inovasi Dan Pembelajaran Fisika, 2(1), 1-11.

Rafli, M. F. (2019). Dampak Implementasi Pembelajaran Berbasis Masalah ( PBM ) dalam Matematika: Kajian Literatur. Jurnal Pendidikan dan Pembelajaran Terpadu (JPPT), 01(01), 31-40. https://doi.org/10.32696/pgsd.v1i1.347.

Safrida, M., \& Kistian, A. (2020). Penerapan Model Pembelajaran Problembased Learning (Pbl) untuk Meningkatkan Hasil Belajar IPA Kelas V Sd Negeri Peureumeue Kecamatan Kaway Xvi. Bina Gogik, 7(1), 53-65.

Saputro, B., Sulasmono, B. S., \& Widyanti, E. (2019). Peningkatan Kemampuan Berpikir Kritis dan Hasil Belajar Matematika Menggunakan Model PBL pada Siswa Kelas V. Jurnal Pendidikan Tambusai, 3(2), 621-631. https://doi.org/10.31004/jptam.v3i1.252.

Shofiyah, N., \& Wulandari, F. E. (2018). Model Problem Based Learning (PBL) dalam Melatih Scientific Reasoning Siswa. Jurnal Penelitian Pendidikan IPA, 3(1), 33. https://doi.org/10.26740/jppipa.v3n1.p33-38.

Simanungkalit, N. A. dan H. T. (2016). Pengaruh Penggunaan Media Pembelajaran Mind Mapping terhadap Prestasi Belajar Matematika Siswa Kelas VII SMP Tunas Baru Jin-Seung Batam Tahun Ajaran 2014/2015. Jurnal Pythagoras, 2(1), 32-37. https://doi.org/10.33373/pythagoras.v5i1.237.

Siregar, P. S., Wardani, L., \& Hatika, R. G. (2017). Penerapan Pendekatan Pembelajaran Aktif Inovatif Kreatif Efektif dan Menyenangkan (Paikem) pada Pembelajaran Matematika Kelas IV SD Negeri 010 Rambah. Jurnal Pemikiran dan Pengembangan Sekolah Dasar (JP2SD), 5(2), 743. https://doi.org/10.22219/jp2sd.vol5.no2.743-749.

Surya, Y. F. (2018). Penerapan Model Pembelajaran Kooperatif Tipe Team Gamestournament (TGT) untuk Meningkatkan Hasil Belajar Matematika Siswa Kelas V Sekolah Dasar Negeri 003 Bangkinang Kota. Jurnal Cendekia: Jurnal Pendidikan Matematika, 2(1), 154-163. https://doi.org/10.31004/cendekia.v2i1.41.

Widiantari N K M, P., Suarjana, I. M., \& Kusmariyatni, N. (2016). Analisis Kemampuan Berpikir Kritis Siswa Kelas IV dalam Pembelajaran Matematika. Journal PGSD Pendidikan Ganesha, 4(1), 1-3. http://dx.doi.org/10.23887/jjpgsd.v4i1.7348.

Widyasari, N. M. ., Meter, I. ., \& Negara, I. G. A. . (2015). Analisis Kesulitan-Kesulitan Belajar Matematika Siswa Kelas IV dalam Implementasi Kurikulum 2013 di SD Piloting Se-Kabupaten Gianyar. MIMBAR PGSD Undiksha, 3(1), 1-11. http://dx.doi.org/10.23887/jjpgsd.v3i1.5069.

Widyastuti, N. S., \& Pujiastuti, P. (2014). Pengaruh Pendidikan Matematika Realistik Indonesia (PMRI) terhadap Pemahaman Konsep dan Berpikir Logis Siswa. Jurnal Prima Edukasia, 2(2), 183. https://doi.org/10.21831/jpe.v2i2.2718.

Wijayama, B. (2020). Peningkatan Hasil Belajar IPA dan Karakter Rasa Ingin Tahu Melalui Model Problem Based Learning Peserta Didik Kelas VI. Jurnal Kreatif : Jurnal Kependidikan Dasar, 10(2), 190-198. https://doi.org/10.15294/kreatif.v10i2.23612.

Yandhari, I. A. V., Alamsyah, T. P., \& Halimatusadiah, D. (2019). Penerapan Strategi Pembelajaran Problem Based Learning untuk Meningkatkan Kemampuan Pemecahahan Masalah Matematis Siswa Kelas IV. Kreano, Jurnal Matematika Kreatif-Inovatif, 10(2), 146-152. https://doi.org/10.15294/kreano.v10i2.19671.

Yoesoef, A. (2015). Penerapan Model Problem Based Learning untuk Meningkatkan Kemampuan Menanya dan Penguasaan Konsep Fisika Kelas X MIA 1 SMA Negeri 2 Kediri. Jurnal Pinus, 1(2), 96-102. https: //doi.org/10.29407/pn.v1i2.154. 